Journal

of Geography,

Politics and Society

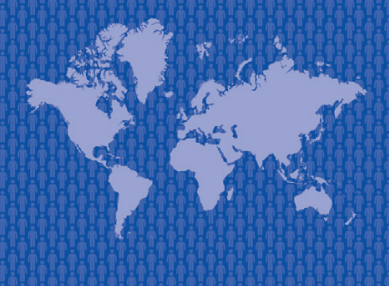

$8(3) / 2018$
Journal of Geography, Politics and Society

$2018,8(3), 25-30$

DOI 10.4467/24512249JG.18.019.8788

\title{
ANALYSIS OF THE ACTUAL NUTRITION STATUS OF SERVICEMEN OF THE TRANSCARPATHIAN REGION WHO PARTICIPATED IN THE ATO AND ITS INFLUENCE ON THE DEVELOPMENT OF THE PATHOLOGY OF THE DIGESTIVE ORGANS
}

\author{
Ivan M. Rogach (1), Angelika O. Keretsman (2), Ivan I. Gadzhega (3)

\begin{abstract}
(1) Department of Social Medicine and Hygiene, Faculty of Medicine, Uzhhorod National University, Pl. Narodna 3, 88000 Uzhhorod Ukraine, e-mail: kaf-socmed@uzhnu.edu.ua (corresponding author)

(2) Department of Social Medicine and Hygiene, Faculty of Medicine, Uzhhorod National University, PI. Narodna 3, 88000 Uzhhorod Ukraine, e-mail: angelika.keretsman@gmail.com

(3) Department of Social Medicine and Hygiene, Faculty of Medicine, Uzhhorod National University, PI. Narodna 3, 88000 Uzhhorod Ukraine,
\end{abstract} \\ e-mail: ivan.gadzhega@uzhnu.edu.ua
}

\section{Citation}

Rogach M., Keretsman A.O., Gadzhega I.I., 2018, Analysis of the actual nutrition status of servicemen of the Transcarpathian region who participated in the ATO and its influence on the development of the pathology of the digestive organs, Journal of Geography, Politics and Society, 8(3), 25-30.

\begin{abstract}
The influence of lifestyle factors, namely rationality of nutrition, on the health of the population is the strongest relative to other risk factors that may be manifested by the development and complication of diseases of the digestive system. This gain is particularly gaining in people who work in conditions of increased stress, physical and psychological overload. To such a contingent of population are also servicemen of the armed forces of Ukraine. This article describes the results of the analysis of the actual state of nutrition of the Transcarpathian military who participated in the anti-terrorist operation in the eastern region of Ukraine.
\end{abstract}

\section{Key words}

antiterrorist operation, servicemen, nutrition, diseases of the digestive system, Ukraine, Transcarpathian region.

\section{Introduction}

Providing optimal nutrition status is one of the most pressing problems facing humanity in the fight against the epidemic of non-infectious diseases, which include diseases of the digestive system (DDS) (Товма, Єгоров, 2013; Чепелевська, 2015). The Armed Forces of Ukraine (the Armed Forces) are an integral part of the state infrastructure and society, carry out specific military and combat tasks, the main of which in recent years is the carrying out of the antiterrorist operation (ATO) in the eastern region of the country.

The conditions of the ATO are characterized by the negative influence of environmental factors, among which the leading place is the influence of 
the military on the organism of the climatologic weather conditions of the terrain, constant stress, lack of sleep, moral and physical exhaustion of the organism, and in particular, inappropriate nutrition.

The organization of high-grade and high-quality nutrition of troops is one of the most important tasks of the medical service. Military food is based on scientific data taking into account the specifics of the service of the soldiers of the Armed Forces. It contributes to the improvement of the health and physical development of servicemen, increases the body's resistance to various physical and mental stresses and, to a large extent, positively affects the combat readiness of troops (Товма, Єгоров, 2013).

During the last decade, increased stress-relatedness at the mass population level has become an inevitable companion of socio-economic and social changes in the state and, naturally, has caused a change in the level and composition of the class of pathology of the digestive organs (HOP), including among military personnel (Швец, Сластин, 2015). As a result, at the end of 2014, almost half of the number of mobilized servicemen who arrived from the troops to the treatment and care facilities for preexamination and the passing of the military medical commission was found unfit for military service with different degrees of restriction. In dismissed from the service for health, the leading place was occupied by stress disorders, cardiovascular diseases, diseases of the nervous system, diseases of the digestive system and only in the fifth place - wounded and injured (Щорічна..., 2017).

Considering that nutrition is one of the main risk factors for the development of non-infectious diseases, including HOP, we consider it expedient to conduct an analysis of the actual state of nutrition of military personnel in the context of the ATO, which determined the purpose and objectives of the study.

The purpose of this article is to study and analyze the problem issues of supplying foodstuffs to the Armed Forces of Ukraine, to determine the directions and ways of its improvement.

In order to study the actual nutrition status of servicemen in the area of ATO, a questionnaire survey of respondents was conducted on the basis of the sociological method. Method and system approach, bibliosemantic and analytical methods are used to analyze problem issues.

\section{Research results}

According to modern scientific views, nutrition standards in terms of nutritional physiology should meet the following basic requirements:
- to contain in certain ratios the required amount of nutrients (proteins, fats, carbohydrates, vitamins, minerals) sufficient to ensure the growth and functioning of the organism;

- provide the body with a certain amount of energy (in potential), sufficient to maintain processes and replenish various energy costs;

- consist of a variety of products that are well absorbed and allow you to prepare delicious and high-calorie foods from them;

- provide hot meals in accordance with the requirements of the diet.

At the same time, the standards of nutrition must meet the economic requirements of the country, the conditions and nature of the work laid. In accordance with the physiological requirements of the body in the diet, proteins should provide 12$15 \%$ of the total energy value of the daily ration, fats - up to $30 \%$, and carbohydrates - up to $55-58 \%$. The standards of nutrition for the personnel of the Armed Forces are developed taking into account the basic requirements of the theory of balanced nutrition and the specific conditions and nature of military labor. Each norm is intended for a certain contingent of servicemen and the total energy value should ensure the replenishment of the energy consumption of this contingent.

The Cabinet of Ministers of Ukraine by Resolution No. 252 of April 29, 2015 (Про внесення..., 2015), introduced changes to the standards of nutrition of servicemen of the Armed Forces and other military formations. For those who participate in the ATO, changes have been made to the standards of nutrition for expanding the range of food, that is, the troops will receive a «flight rate». That is, such as for a combat pilot who performs tasks with overload. Calorie content of servicemen involved in the execution of combat missions, brought to 4800 kilocalories (kKal) norms of supply of bottled water - up to three liters per day. Also, in the area of ATO, starting in April 2014, the system of food security is being expanded. Today, in cooperation with the Center for Development and Support of Material Support of the Armed Forces of Ukraine, new dry solips were developed according to NATO standards, which provided assistance in their development (Про внесення..., 2016).

In order to study the actual state of nutrition of servicemen in the area of ATO, we conducted a questionnaire survey among military personnel of the military unit A1556 of Uzhhorod, Zakarpattia oblast, where at the time of the study there was a personnel of 128 separate mountain infantry brigades (OGPB). This unit actively participated in the ATO during the last 3 years. The last transfer of the brigade to the 
combat zone was in June 2017, and the withdrawal from the zone ATO - in December 2017.

In total, 166 people took part in the survey: 147 military personnel and 19 military medical personnel (doctors and nurses). Respondents answered the questions regarding the quantitative and qualitative composition of the daily diet. In particular, which particular groups of products are part of the dishes they used to be in the ATO zone. As the results of statistical data show, the overwhelming majority of servicemen note the lack of daily food rations of fresh food - vegetables and fruits, meat and bakery products, and, in particular, dairy products (Fig. 1).

Thus, the overwhelming majority of respondents (86.3\%) noted a very low level of availability of fresh vegetables and fruits. Moreover, $66.1 \%$ of them stressed that the lion's share of cases when they still received vegetables and fruits was due to the initiative, organization and honesty of volunteer organizations. At the same time, $82.7 \%$ of respondents noted the very low level of supply of meat products (fresh and frozen). After all, even an updated dry solder contains canned meat. At the same time, 93.1\% of respondents stress that even when the products described above came to the location of the unit, their number did not allow to adequately distribute this stock for a long period. The main reason for this situation was the lack of cooling devices in the specific conditions of the unit's dislocation, especially in the summer. In the case of dried meat products, $74.9 \%$ of the polled soldiers also indicated a low level of security.
A small proportion of servicemen (4.2\%), who responded to the lack of milk and dairy products, was explained by the fact that the majority of respondents did not answer the questionnaire on the issues related to the provision of this group of food products. In the verbal conversation, the answer to the answer was explained by the almost complete absence of the products of this group in their diets of daily nutrition. We also received similar replies regarding fresh bread and bakery products. Based on the data obtained from the questionnaires, only $7.8 \%$ of respondents indicated their lack of, other respondents did not answer this question by commenting on the fact that in most cases they bought them at their own expense in order to use the maximum-fresh products of this groups daily.

The questionnaire also included questions about the sources of food in their subdivision. In particular, what proportion of the availability of the given resource of their brigade belongs to the Ministry of the Armed Forces of Ukraine, volunteer organizations, local residents, and the proportion of products purchased at their own expense (Fig. 2).

As can be seen from the results presented, the vast majority of food products $(47.1 \%)$ come into the zone of combat operations precisely because of the initiative, perseverance and sustainability of volunteer organizations. The Armed Forces, financed by the state, according to military personnel, provide only $32.8 \%$ of food revenues in the area of combat operations. $19.9 \%$ of all food products soldiers are looking for themselves and buy at their own

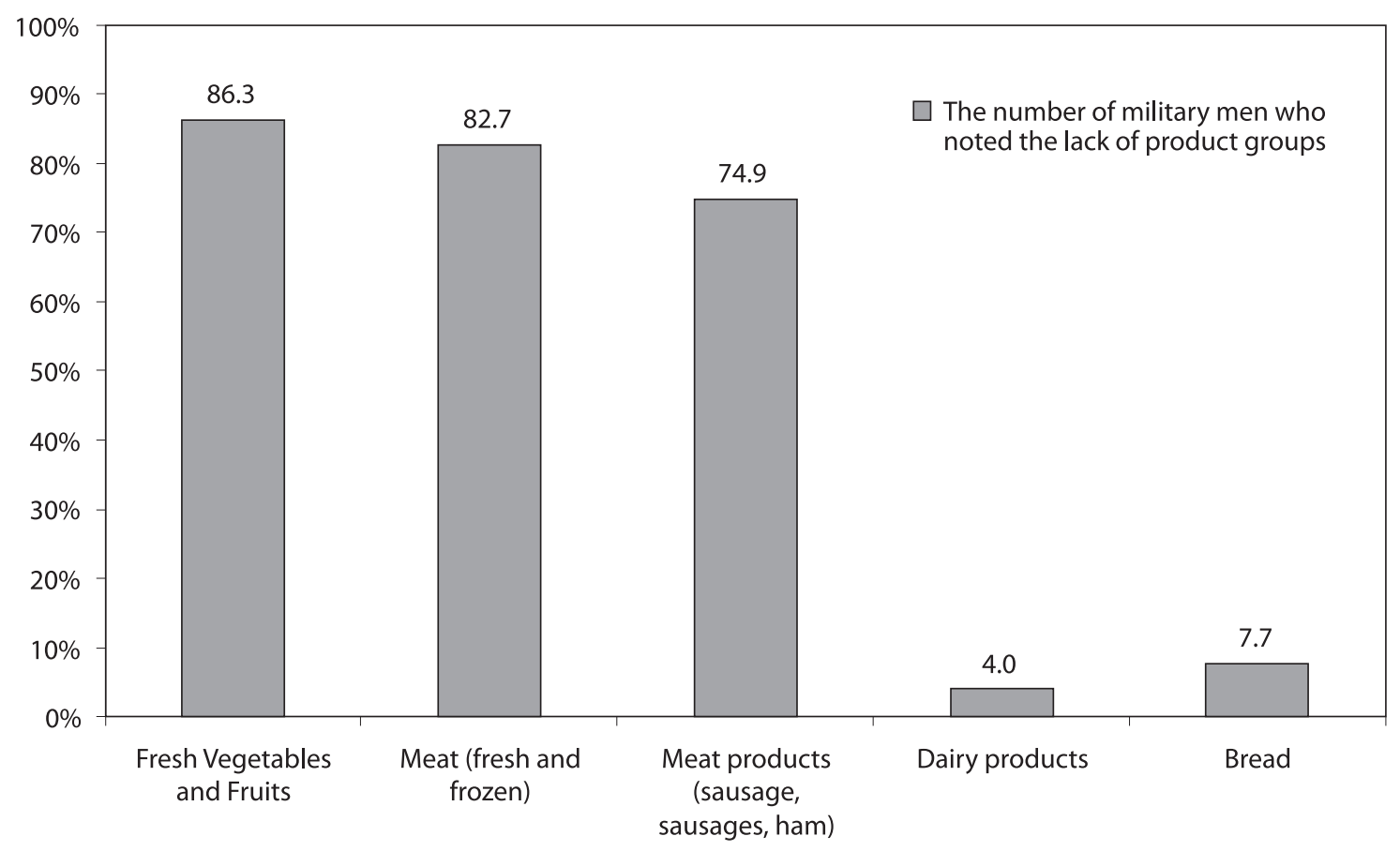

Fig. 1. The level of lack of major food groups

Source: own research (results of the questionnaire). 


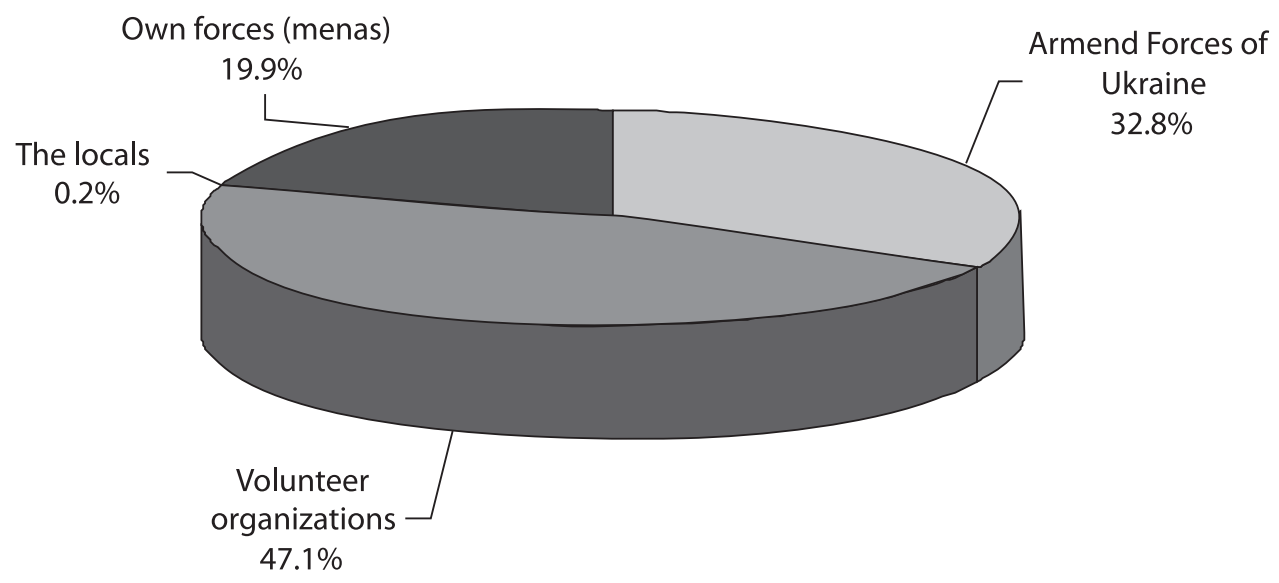

Fig. 2. The share of sources of food income to military units in the zone of ATO

Source: own research (results of the questionnaire).

expense. And only in $0.2 \%$ of cases the aid comes from the inhabitants who stayed in the territory of carrying out of hostilities.

We also conducted an analysis of responses regarding manifestations of gastroenterological diseases among this contingent of military personnel. $100 \%$ of respondents emphasize the functional manifestations of gastroenterological diseases: cramping, burping, bloating, discomfort in the abdominal cavity, violations of physiological items, heartburn, and the like. In $76.5 \%$ of the military (127 people), two weeks later, pain was noted: $59.0 \%$ in the stomach, $48.5 \%$ in the left hypochondrium, $89.0 \%$ in the intestine. All respondents indicated that the occurrence of pain and functional gastroenterological disorders were due to food intake. Thus, in $76.0 \%$ of cases, these manifestations were associated with inappropriate nutrition, when, due to the impossibility of three meals a day (during the intensification of hostilities), significant interruptions were observed between meals. $89.2 \%$ of the functional manifestations of the servicemen are associated with overstress and stress, in $56.4 \%$ of cases - with the "admission" of the main set of food products, and $83.0 \%$ - with a lack of fresh food.

Summarizing the results of the conducted analysis, one can state the lack of daily food rations of servicemen who were in the zone of combat operations ATO, fresh food. The current standard field ration of a Ukrainian soldier does not spoil the diversity. Daily dry rations include a breakfast, lunch and dinner menu. Breakfast may consist of canned pastas, pearl porridge with beef and cooked bread. The lunch menu consists of a canned "tourist's breakfast" and the same gastronomic cookie. Finally, for dinner, buckwheat porridge with beef (again in canned food), grate again, tea and honey in stickers can be served. In addition to the "dry ration", tea and coffee in bags, sugar and hygienic napkins are both dry and wet. In this set of products, hunger can be frozen, but the appearance of canned food looks rather unpopular.

In Western armies, the main dishes for soldiers consist of natural food. The daily diet of the US Army soldier Meal Ready to Eat (MRE) includes 24 dishes, one of which is vegetarian. The soldier will know what exactly he should eat when he opens a package with dry rations. Food can be warmed up with a special chemical that should be diluted with water so that it begins to heat.

In addition to food in rations include all sorts of things, such as matches, packing with chewing gum, a tube with a sauce, as well as a set of sanitary napkins.

Soldiers of British Army soldiers and soldiers of the German Bundeswehr get packed in a box of thick foil (in such boxes, sometimes feeding to aircraft passengers). At the same time, the compilers of British and German rations respect the national traditions, investing in the solder the necessary products: the British even in the trenches love to drink tea, and German sausage is known all over the world (Ветров, 2016).

By the decree of the Cabinet of Ministers dated October 3, 2016, No. 696 «On Amendments to the Nutrition Standards of Servicemen of the Armed Forces and Other Military Forces» (Про внесення..., 2016), the standards of nutrition have been improved, provision is made for an occasional (breakfast, lunch, dinner) issue of a new norm taking into account the amount of rations necessary to provide troops a full meal. Thanks to the new packaging technologies (retort pack), ready-made dishes can be obtained without pre-heat treatment, which will ensure compactness and ease of use during use. In the area of ATO in the norm, it is assumed to use 
a nonflammable heater of food, which will allow servicemen to independently provide themselves with hot meals without exposing their location to the enemy. However, according to one of the information services (Бірюков, 2014) in an interview with the advisor to the President of Ukraine, only 23 hryvnias are allocated per day for one soldier of the Armed Forces, even taking into account the «airspace norm» in the zone of the ATO's activity. At the same time, the state only reimburses the cost of the food service, and the purchase of food lies with commercial enterprises that have entered into an agreement to feed the Armed Forces (their 4). That is, all parts of the Armed Forces in the ATO zone have the same norm, serviced by the same companies from the same warehouses. At the same time, they are not in a position to provide cooking in the field, the food is cooked by the military themselves (chefs). Thus, the main problem in the ATO environment is the provision of a variety of food products and the delivery of basic, in particular, fresh food. After all, on the distant fronts delivery of food products is carried out by the military units themselves.

In such a situation, in the future, even after returning to military units outside the ATO's area, conditions for a better quality and adequate nutrition that corresponds to daily needs and norms should allow the soldier's contingent to display manifestations of violations of the digestive system. After all, it is well-known that the main factors of the development of pathologies of the DDS class are irrational and inferior nutrition, stress, bad habits, untimely diagnosis and treatment of gastroenterological diseases, etc. (Чепелевська, 2015).

At the heart of the preventive measures of the onset and progression of HOP is not only the reduction of the stress level of the given contingent population, but also the provision of its high quality, fresh products in the optimum quantity for the purpose of preparation of useful and nutritious food.

\section{Conclusions}

The result of this work it was concluded:

1. The importance and relevance of the problem studied requires further study in order to improve the management and distribution of food in medical units of the armed forces of Ukraine. The first step can be the participation of medical staff in the organization of providing medical formations with food in order to prevent the onset and complication of diseases of the gastrointestinal tract.
2. The modern provision of military forces with products, their delivery and preparation systems are based on Soviet principles with some modern additions, and therefore requires full revision and improvement in connection with changes in production technologies in the food industry, as well as changes in the health of the population of Ukraine at the present stage.

3. A detailed analysis of the existing experience of providing food to troops in the ATO zone indicates the existence of a number of unresolved problems of their actual nutrition: the lack of fresh food products, their storage conditions and their diversity, due to the peculiarities of delivery to military units.

4. In such a situation, state priority measures should be to ensure a mechanism for the delivery of food products and the quality of their preparation, if necessary, by participating in the process of providing the servicemen of the relevant specialists, in particular representatives of logistics enterprises and cooks.

5. Based on the analysis, the influence of the actual nutritional status of servicemen in the zone of ATO on the risk of development of gastroenterological diseases was revealed. In particular, it has been proven that prolonged irrational nutrition (inadequate and inadequate nutrition for its qualitative and quantitative composition) poses a risk of developing pathologies of the class of digestive organs, even upon returning to normal nutritional conditions.

6. Provision of food for servicemen needs further improvement of its normative and legal regulation concerning the mechanism of delivery of food to the zone of ATO, in particular during active military operations.

7. In the interests of strengthening the state's defense capability and maintaining the health of servicemen, when developing a nutrition policy, it is necessary to rely on the existing mechanisms for providing food for servicemen in combat situations, taking into account international experience and experience gained during the ATO.

\section{References}

Бірюков Ю., 2014, Як годують військових у зоні АТО. Розповідь волонтера, iPress.ua, http://ipress.ua/ljlive/ yak_goduyut_viyskovyh_u_zoni_ato_rozpovid_ volontera_99946.html [23.03.2018].

Ветров І., 2016, Чим пайок солдатів ЗСУ відрізняється від закордонних: західна кухня в українській армії, Сьогодні, https://ukr.segodnya.ua/ukraine/chem-paek-soldat- 
vsu-otlichaetsya-ot-zagranichnyh-zapadnaya-kuhnya-vukrainskoy-armii-688146.html [23.03.2018].

Про внесення змін до норм харчування військовослужбовців Збройних Сил та інших військових формувань, 2015, Постанова Кабінету Міністрів України № 252 від 29 квітня 2015 р., Сьогодні, http://zakon5.rada.gov.ua/ laws/show/252-2015-п [21.03.2018].

Про внесення змін до норм харчування військовослужбовців Збройних Сил та інших військових формувань, 2016, Постанова Кабінету Міністрів України № 696 від 3 жовтня 2016 р., Сьогодні, http://zakon3.rada.gov.ua/laws/ show/696-2016-п [23.03.2018].

Товма Л.Ф., Єгоров Д.В., 2013, Вдосконалення продовольчого забезпечення військових частин та підрозділів внутрішніх військ в умовах комплектування військовослужбовцями військової служби за контрактом, Збірник наукових праць Харківського університету Повітряних Сил, 4(37), 229-232.

Чепелевська Л.А., 2015, Сучасні проблеми смертності населення України від хвороб органів травлення, Україна. Здоров'я начії, 1(33), 15-21.

Швец О.В., Сластин В.В., 2015, Безопасность и качество пищевых продуктов в контексте охраны общественного здоровья, Східноєвропейський журнал громадського здоров'я, 1(22), 20-25.

Щорічна доповідь про стан здоров'я населення, санітарно-епідемічну ситуацію та результати діяльності системи охорони здоров'я України, 2016 рік, 2017, МО3 України, ДУ «УІСД МОЗ України», Київ. 